\title{
Needle Stick Induced Arbovirus Infection: A New Problem That Should not be Forgotten
}

\author{
Beuy Joob, ${ }^{1, *}$ and Viroj Wiwanitkit ${ }^{2}$ \\ ${ }^{1}$ Sanitation 1 Medical Academic Center, Bangkok, Thailand \\ ${ }^{2}$ Visiting Professor, Hainan Medical University, China \\ "Corresponding author: Beuy Joob, Sanitation 1 Medical Academic Center, Bangkok, Thailand. E-mail: beuyjoob@hotmail.com
}

Received 2017 March 15; Accepted 2017 March 25.

\section{Dear Editor,}

Arbovirus infection is still an important medical problem, which is mainly transmitted by mosquito bite. There are many reports on atypical modes of transmission, and needle stick injury as a mode of transmission of arbovirus infection is rarely mentioned. This is an important but forgotten issue in occupational health for the medical personnel. Of several arbovirus infections, needle stick injury related dengue infection is well- mentioned (1). It is classified as an important kind of nosocomial infection. Interestingly, needle stick injury related dengue infection has already been reported in many non-tropical countries (2-4). Hence, this problem can occur anywhere in the world.

Needle stick injury is a common accident in medical procedures and can be done by any medical personnel. The possibility of arbovirus transmission by needle stick injury accident should not be neglected. In the present worldwide outbreak of Zika virus infection, the great concern on the possibility of needle stick injury transmission of Zika virus should be discussed although there is still no confirmed case report.

\section{Footnote}

\section{Conflict of Interest: None.}

\section{References}

1. Wiwanitkit V. Unusual mode of transmission of dengue.J Infect Dev Ctries. 2009;4(1):51-4. [PubMed: 20130380].

2. Morgan C, Paraskevopoulou SM, Ashley EA, Probst F, Muir D. Nosocomial transmission of dengue fever via needlestick. An occupational risk. Travel Med Infect Dis. 2015;13(3):271-3. doi: 10.1016/j.tmaid.2015.03.016. [PubMed: 25936825].

3. Lee C, Jang EJ, Kwon D, Choi H, Park JW, Bae GR. Laboratory-acquired dengue virus infection by needlestick injury: a case report, South Korea, 2014. Ann Occup Environ Med. 2016;28:16. doi: 10.1186/s40557-016-0104-5. [PubMed: 27057314].

4. Ohnishi K. Needle-stick dengue virus infection in a health-care worker at a Japanese hospital.J Occup Health. 2015;57(5):482-3. doi: 10.1539/joh.14-0224CS. [PubMed: 26084918]. 